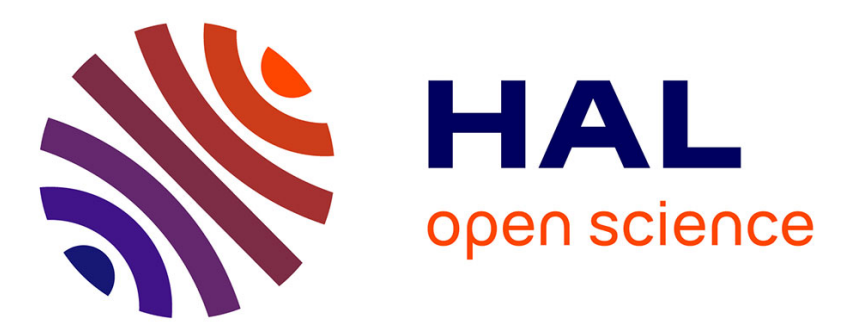

\title{
Stress-induced Intercellular Communication Remodeling in the Rat Adrenal Medulla
}

\author{
Claude Colomer, Chrystel Lafont, Nathalie C. Guérineau
}

\section{To cite this version:}

Claude Colomer, Chrystel Lafont, Nathalie C. Guérineau. Stress-induced Intercellular Communication Remodeling in the Rat Adrenal Medulla. Annals of the New York Academy of Sciences, 2008, 1148 (1), pp.106-111. 10.1196/annals.1410.040 . hal-02484222

\section{HAL Id: hal-02484222 \\ https://hal.science/hal-02484222}

Submitted on 19 Feb 2020

HAL is a multi-disciplinary open access archive for the deposit and dissemination of scientific research documents, whether they are published or not. The documents may come from teaching and research institutions in France or abroad, or from public or private research centers.
L'archive ouverte pluridisciplinaire HAL, est destinée au dépôt et à la diffusion de documents scientifiques de niveau recherche, publiés ou non, émanant des établissements d'enseignement et de recherche français ou étrangers, des laboratoires publics ou privés. 
Abbreviated running title: Colomer et al.: stress and cell-cell communication in adrenal medulla

\section{Stress-induced intercellular communication remodeling in the rat adrenal medulla}

Claude Colomer ${ }^{\mathrm{a}, \mathrm{b}, \mathrm{c}, \mathrm{d}}$, Chrystel Lafont ${ }^{\mathrm{a}, \mathrm{b}, \mathrm{d}, \mathrm{d}}$ and Nathalie C. Guérineau ${ }^{\mathrm{a}, \mathrm{b}, \mathrm{d}, \mathrm{d}}$

${ }^{a}$ Institute of Functional Genomics, Department of Endocrinology, Montpellier, France

${ }^{\mathrm{b}} \mathrm{CNRS}$ UMR5203, Montpellier, France

${ }^{\circ}$ INSERM U661, Montpellier, France

${ }^{\mathrm{d}}$ University of Montpellier (IFR3), Montpellier, France

Corresponding author: Dr. Nathalie C. Guérineau, IGF, Department of Endocrinology, 141 rue de la Cardonille, 34094 Montpellier cedex 5, France.

E-mail: nathalie.guerineau@igf.cnrs.fr

Tel: (33)-4-67-14-29-59

FAX: (33)-4-67-54-24-32

Keywords: intercellular communication, synaptic currents, gap junctional coupling, chromaffin cell excitability, cold exposure, acute rat adrenal slices, dye transfer

This work was supported by grants from Centre National de la Recherche Scientifique, Institut National de la Santé et de la Recherche Médicale, Réseau National des Génopôles, and Région Languedoc-Roussillon. 


\begin{abstract}
To understand the mechanisms by which a prolonged exposure to stress enhances catecholamine secretion, we examined the effects of a 5-day cold exposure on cell-cell communication pathways in the rat adrenal medulla. Upon stress, the neurosecretory tissue undergoes dramatic morpho-functional changes resulting in increased chromaffin cell excitability, up-regulation of both chemical transmission at the splanchnic nerve terminal-chromaffin cell synapses and spreading of gap junction-permeant Lucifer yellow between cells. All these changes converge to improve the stimulus-secretion coupling efficiency within the adrenal medulla and subsequently to adapt catecholamine release to a sustained organism demand.
\end{abstract}

\title{
Introduction
}

Stress triggers important adaptative responses that enable an organism to cope with a changing environment. An increase in catecholamine secretion (epinephrine and norepinephrine) by adrenal chromaffin cells is a key initial event in response to stressors. Prolonged or repetitive stress is commonly associated with a sustained catecholamine concentration in the blood circulation. Investigating the regulatory mechanisms involved in the secretion of catecholamines is therefore a crucial step to better understand adaptative responses to stress. In vivo, the secretion of catecholamines by chromaffin cells is chiefly controlled by the synaptic release of acetylcholine from splanchnic nerve terminals ${ }^{1}$. In addition, as previously reported in adrenal acute slices ${ }^{2}$, gap junction-mediated intercellular communication between chromaffin cells represent an efficient complement to synaptic transmission to amplify catecholamine release. The aim of this study is to characterize morphological and functional changes that occur in the adrenal medullary gland of stressed rats, using a 5-day cold exposure as a stress paradigm ${ }^{3}$. Our results show that stress remodels both chemical synaptic transmission and cell-cell communication likely mediated by gap junctions.

\section{Material and Methods}

Stress paradigm. Wistar male rats (6 week-old) were kept at an ambient temperature of $4^{\circ} \mathrm{C}$ for 5 days. The room was maintained on a 12-hour light/dark cycle. Food and water were provided ad libitum. The reversibility of stress-induced changes was examined 5 days after stress cessation.

Slices preparation. Acute rat adrenal slices were prepared as reported previously ${ }^{2}$. Slices (200 $\mu \mathrm{m}-$ thick) were cut using a vibratome and transferred to a storage chamber containing Ringer's saline (in $\mathrm{mM}$ ): $125 \mathrm{NaCl}, 2.5 \mathrm{KCl}, 2 \mathrm{CaCl}_{2}, 1 \mathrm{MgCl}_{2}, 1,25 \mathrm{NaH}_{2} \mathrm{PO}_{4}, 26 \mathrm{NaHCO}_{3}, 12$ glucose, maintained at $37^{\circ} \mathrm{C}$ and buffered to $\mathrm{pH}$ 7.4. The saline was continuously bubbled with carbogen $\left(95 \% \mathrm{O}_{2} / 5 \% \mathrm{CO}_{2}\right)$. 
Electrophysiological recordings. All experiments were performed in the whole-cell configuration of the patch-clamp technique ${ }^{4}$. Patch pipettes were filled with (in $\mathrm{mM}$ ): $140 \mathrm{~K}$-gluconate, $2 \mathrm{MgCl}_{2}, 1.1$ EGTA, 5 Hepes, pH 7.2. Recordings were aquired with an EPC-9 patch-clamp amplifier. Spontaneous post-synaptic excitatory currents EPSCs were recorded as described ${ }^{5}$.

Immunostaining. To process for immunolabeling, the adrenal glands were fixed by immersion in $4 \%$ paraformaldehyde (PFA) in $0.1 \mathrm{M}$ phosphate buffer (overnight at $4^{\circ} \mathrm{C}$ ). They were then cut into 50 $\mu \mathrm{m}$-thick sections. The $200 \mathrm{kDa}$ neurofilaments were labeled using a polyclonal antibody (NF-200, Sigma, 1:2000 dilution, $48 \mathrm{~h}$ incubation, $4^{\circ} \mathrm{C}$ ). Stained sections were imaged with a Biorad MRC-1024 confocal laser scanning microscope.

Scrape loading dye-transfer. This technique allows to introduce the gap junction-permeant fluorescent dye, Lucifer yellow $\mathrm{CH}(\mathrm{LY})$ into cells and to monitor its propagation into communication-competent cells within minutes after loading ${ }^{6}$. After ablation, adrenal glands were hemi-sectioned with a razor blade, incubated at room temperature for $3 \mathrm{~min}$ in $0.5 \% \mathrm{LY}$-containing saline and then fixed in $4 \%$ PFA in $0.1 \mathrm{M}$ phosphate buffer (2h, room temperature). To visualize LY staining, each hemi-gland was then sliced (100 $\mu \mathrm{m}$ thickness). The dye spreading was quantified by calculating the surface rendering of the fluorescence ${ }^{7}$ (Imaris ${ }^{\circledR}$ 4.5.2, Bitplane, Switzerland).

Statistics. Numerical data are expressed as the mean \pm sem. The Student $t$ test was used to compare means. Percentages were compared using the Khi2 test. Differences of $p<0.001$ were considered significant.

\section{Results}

\section{Increased chromaffin cell excitability in stressed rats}

The measurement of passive electrical properties of individual chromaffin cells indicates that both the membrane capacitance, the membrane input resistance and the resting potential significantly differed between stressed and unstressed rats $(\mathrm{p}<0.001$, table 1). Five days after cessation of the stress situation, these parameters recovered their control values. Regarding action potential firing, $82.6 \%$ of cells exhibited spontaneous action potentials at rest in stressed rats $(n=799)$ while only $27.5 \%$ of cells were spontaneously active in controls $(n=590, p<0.001)$. In addition, stress increased the mean spontaneous discharge frequency $(4.42 \pm 0.16 \mathrm{~Hz}, \mathrm{n}=209$ versus $2.85 \pm 0.11 \mathrm{~Hz}, \mathrm{n}=142$ in stress and control conditions, respectively, Figure 1A-B), thus reflecting an increase in cell excitability.

\section{Stress-induced changes in synaptic transmission at the splanchnic nerve-chromaffin cell junction}

Because the catecholamine release by chromaffin cells is chiefly regulated trans-synaptically via splanchnic nerve firing, we next investigated whether chromaffin cell innervation was affected upon 
cold exposure. The innervation density was visualized by the immunofluorescent detection of the 200 $\mathrm{kDa}$ neurofilament, a neuron-specific intermediate filament protein ${ }^{8}$. As illustrated in figure $2 \mathrm{~A}$, stress increased the density of neuronal fibers synapsing onto chromaffin cells. To address the physiological relevance, spontaneous EPSCs were recorded in chromaffin cells voltage-clamped at -80 mV (Figure 2B). In cold exposed rats, not only the percentage of recorded cells exhibiting spontaneous EPSCs was higher compared with controls $(22 \%$ versus $6 \%, \mathrm{n}=225)$, but also synaptic events occurred more frequently $(0.12 \pm 0.01 \mathrm{~Hz}, \mathrm{n}=50$ versus $0.04 \pm 0.01 \mathrm{~Hz}, \mathrm{n}=13$ for stress and control, respectively).

\section{Up-regulated intercellular communication in stressed rats}

As previously reported $^{2}$, the gap junction-delineated route efficiently complements synaptic transmission to amplify catecholamine secretion from chromaffin cells. We therefore performed additional experiments to determine whether cell-cell coupling was modified upon stress. Lucifer yellow, a gap junction-permeant dye able to image coupled cells was introduced into cells by using the scrape loading technique ${ }^{6}$. Figure 3 illustrates representative examples of confocal stack image of LY diffusion in control and stressed rats. As shown by the 3D analysis of the surface rendering of fluorescent voxels, the spreading of LY was more extended in cold exposed rats as compared with unstressed rats. This strongly suggests that gap junction-mediated intercellular communication is upregulated in stressed rats.

\section{Discussion}

The present study unveils morpho-functional changes that occur in the adrenal medulla after prolonged exposure to cold. All converge to an increased catecholamine secretion as commonly observed upon stressful conditions. Firstly, collective results from electrophysiological data including i) a more depolarized resting potential, ii) an increased number of cells exhibiting spontaneous action potentials and iii) an increased mean spontaneous discharge frequency argue in favor of stress-induced increased chromaffin cell excitability. In addition, the denser innervation of the adrenal medulla found in stressed rats and the subsequent increase in EPSC frequency in chromaffin cells also contribute to improve the stimulus-secretion coupling efficiency.

Although adrenomedullary secretory responses to cold are small compared to sympathetic neuronal responses, exposure to cold is known to increase the synthesis and the release of adrenomedullary catecholamines $^{3,9}$. Regarding catecholamine biosynthesis, our results describing an increased innervation of the medulla are consistent with the hypothesis of the involvement of neurotransmitters released from the splanchnic nerve in the induction of tyrosine hydroxylase in the adrenal medulla of stressed rats ${ }^{10}$. With regard to catecholamine secretion, stress-induced increase in action potential firing likely contributes to elevate cytosolic calcium concentration and ensuing catecholamine 
release $^{11}$. Secondly, cell-cell communication that has been previously reported to amplify catecholamine secretion $^{2}$ is also up-regulated in stressed rats. This is supported by our scrape-loading experiments showing an extended spreading of LY in the adrenal medulla of cold exposed rats. As an independent confirmation, chromaffin cells from stressed rats display electrophysiological features that are consistent with an enhancement of electrical coupling, i.e. a significant increase in membrane capacitance and a significant decrease in membrane resistance. It is noteworthy that comparative morpho-functional modifications also occur in the adrenal medulla of rats exposed to a restraint stress (data not shown), suggesting that the reshapes reported here might commonly occur in response to various stressors. We propose that synaptic transmission and gap junctional coupling by acting in synergy on chromaffin cells likely contribute to improve the stimulus-secretion coupling efficiency in the adrenal gland and subsequent increased catecholamine secretion commonly observed in response to stressors.

\section{References}

1. Axelrod, J. 1971. Noradrenaline: fate and control of its synthesis. Science 173: 598-606.

2. Martin, A.O., et al. 2001. Gap junctions mediate electrical signaling and ensuing cytosolic $\mathrm{Ca}^{2+}$ increases between chromaffin cells in adrenal slices: A role in catecholamine release. J. Neurosci. 21: 5397-5405.

3. Kvetnansky, R., et al. 1971. Catecholamine-synthesizing enzymes in the rat adrenal gland during exposure to cold. Am. J. Physiol. 220: 928-931.

4. Hamill, O.P., et al. 1981. Improved patch-clamp techniques for high-resolution current recording from cells and cell-free membrane patches. Pflügers Arch. 391: 85-100.

5. Martin, A.O., et al. 2003. Evidence for long-lasting cholinergic control of gap junctional communication between adrenal chromaffin cells. J. Neurosci. 23: 3669-3678.

6. El-Fouly, M.H., Trosko, J.E. \& Chang, C.C. 1987. Scrape-loading and dye transfer. A rapid and simple technique to study gap junctional intercellular communication. Exp. Cell Res. 168: 422-430.

7. Bonnefont, X., et al. 2005. Revealing the large-scale network organization of growth hormonesecreting cells. Proc. Natl. Acad. Sci. 102: 16880-16885.

8. Trojanowski, J.Q., Walkenstein, N. \& Lee, V.M. 1986. Expression of neurofilament subunits in neurons of the central and peripheral nervous system: an immunohistochemical study with monoclonal antibodies. J. Neurosci. 6: 650-660.

9. Gordon, R., et al. 1966. Increased synthesis of norepinephrine and epinephrine in the intact rat during exercise and exposure to cold. J. Pharmacol. Exp. Ther. 153: 440-447. 
10. Kvetnansky, R. \& Sabban, E.L. 1993. Stress-induced changes in tyrosine hydroxylase and other catecholamine biosynthetic enzymes. In Tyrosine Hydroxylase: From Discovery to Cloning. M. Naoi \& S.H. Parvez, Eds.:253-281. VSP Press, Utrecht.

11. Kidokoro, Y. \& Ritchie, A.K. 1980. Chromaffin cell action potentials and their possible role in adrenaline secretion from rat adrenal medulla. J. Physiol. (Lond) 307: 199-216.

\section{Figure legend}

Figure 1: Increased frequency of spontaneous action potential firing in chromaffin cells of stressed rats

A. Representative example of spontaneous firing pattern recorded in a control (left chart) and in a stressed chromaffin cell (right chart). Cells were current-clamped at their resting membrane potential (52 and $-63 \mathrm{mV}$, respectively). B. Pooled data showing a significant increase in action potential mean frequency in stressed rats $(*, p<0.001)$. The number of recorded cells is indicated in parentheses.

\section{Figure 2: Stress-induced morphological and associated functional changes of the adrenal medulla innervation}

A. Immunofluorescent detection of $200 \mathrm{kDa}$ neurofilaments (NF-200, polyclonal antibody, 1:2000 dilution ; secondary antibody conjugated to Alexa fluor 488, 1:2000 dilution) showing an increased density of neuronal fibers innervating the adrenal medulla in stressed rat (white arrows). B. Representative recordings of spontaneous EPSCs. Pooled data show a significant increase in synaptic current frequency in stressed rats (cells voltage-clamped at $-80 \mathrm{mV}$, synaptic currents recorded for at least $10 \mathrm{~min}, *, \mathrm{p}<0.001)$.

\section{Figure 3: Stress-induced increase in cell-cell communication in the adrenal medulla}

The cell-cell communication extent was assessed by using the scrape-loading technique to label coupled cells. Left panel: confocal image stack of LY spreading (6 slices/stack, C: cortex, M: medulla). Right panel: 3D analysis by using surface rendering of fluorescent voxels. 


\begin{tabular}{|c|c|c|c|}
\hline & $\begin{array}{c}\mathrm{Cm} \\
(\mathrm{pF})\end{array}$ & $\begin{array}{c}\mathrm{Rm} \\
(\mathrm{M} \Omega)\end{array}$ & $\begin{array}{c}\text { resting potential } \\
(\mathrm{mV})\end{array}$ \\
\hline $\begin{array}{c}\text { control } \\
(\mathrm{n}=590)\end{array}$ & $10.3 \pm 0.1$ & $1597 \pm 15$ & $-64.4 \pm 0.3$ \\
\hline $\begin{array}{c}\text { cold exposure } \\
(\mathrm{n}=799)\end{array}$ & $10.7 \pm 0.1^{*}$ & $1430 \pm 13^{*}$ & $-62.2 \pm 0.3^{*}$ \\
\hline $\begin{array}{c}\text { recovery } \\
(\mathrm{n}=142)\end{array}$ & $10.5 \pm 0.1$ & $1595 \pm 9$ & $-64.4 \pm 0.2$ \\
\hline
\end{tabular}

TABLE 1: Comparison of passive electrophysiological properties of adrenal chromaffin cells between control and stressed rats. 

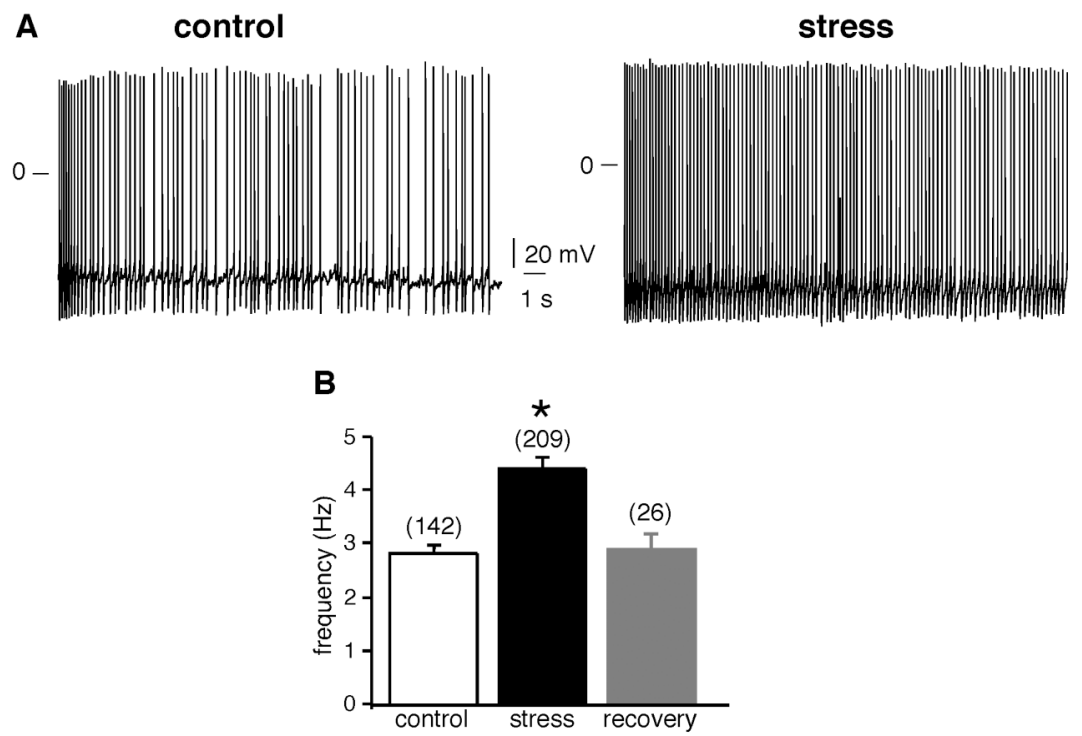

FIGURE 1 
A control

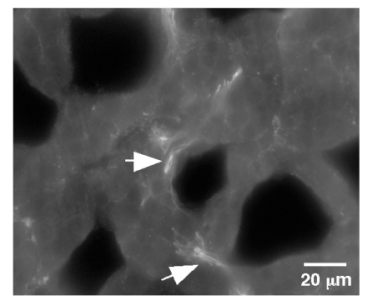

B control

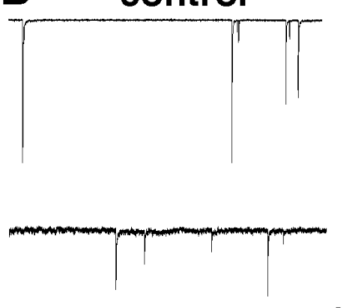

stress

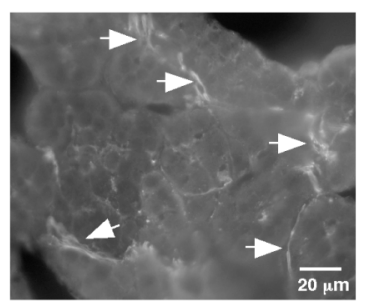

stress

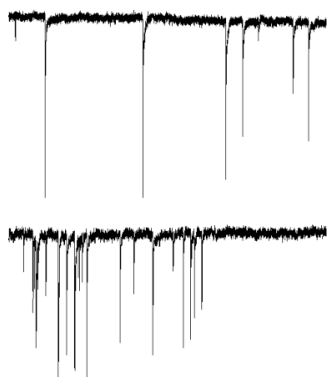

$\frac{150}{10 \mathrm{~s}}$

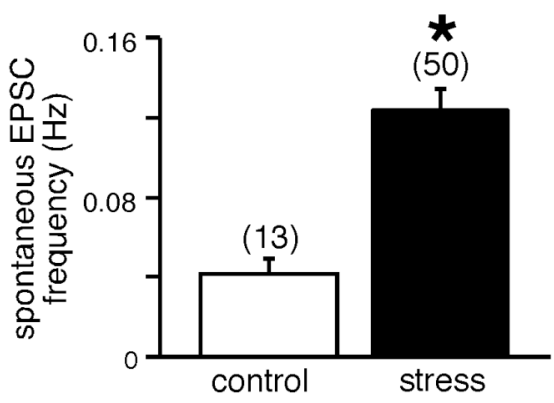

FIGURE 2 


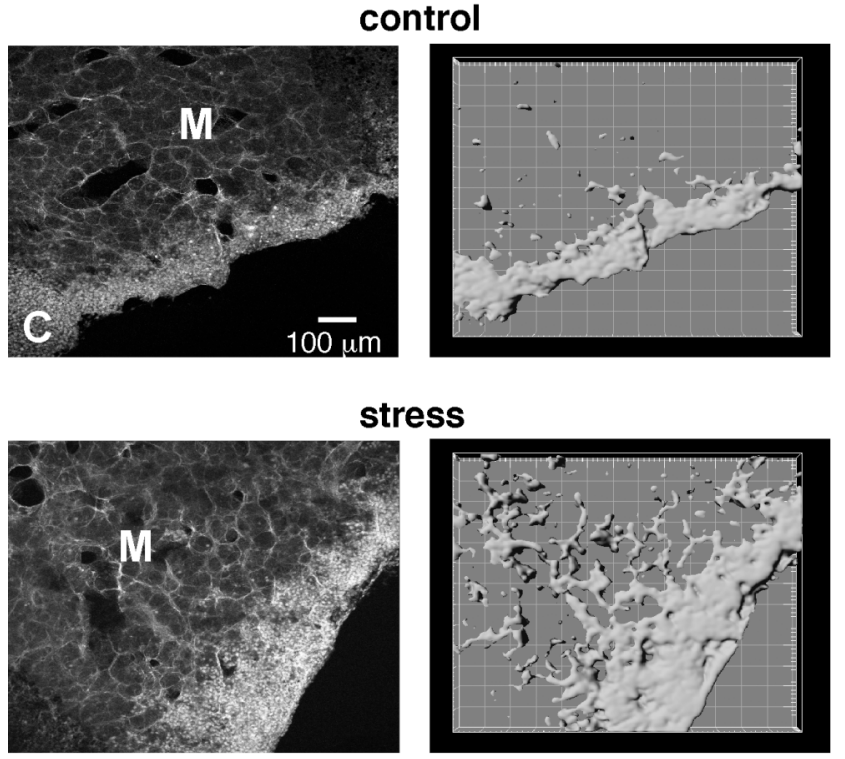

FIGURE 3 